\title{
THE TRANSPOSITION OF THE BALANCE SHEET TO FINANCIAL AND FUNCTIONAL BALANCE SHEET. RESEARCH AND DEVELOPMENT
}

\author{
Liana GĂDĂU \\ Spiru Haret University, Bucharest \\ E-mail: lianagadau@yahoo.com
}

\begin{abstract}
As the title suggests, through this paper we want to highlight the necessity of treating again the content and the form of the balance sheet in order to adapt it to a more efficient analysis, this way surpassing the informational valences of the classic balance sheet.

The functional and the financial balance sheet will be taken into account. These models of balance sheet permit the complex analyses regarding the solvability or the bankruptcy risk of an enterprise to take place, and also other analyses, like the analysis of the structure and the financial/ functional equilibrium, the analysis of the company on operating cycles and their role in the functioning of the company. Through the particularities offered by each of these two models of balance sheet, we want to present the advantages of a superior informing. This content of this material is based on a vast investigation of the specialized literature.
\end{abstract}

Keywords: the balance sheet, the financial balance sheet, the functional balance sheet, the liquidity - exigibility criteria, the functional criteria

JEL Classification: $M_{40}, M_{41}$

\section{Introduction}

The balance sheet is draw up based on some accounting recommendations and national laws. Therefore, the content and the presentation of the balance sheet are normalized and fixed. When this document is examined in terms of exigibility and solvability, but also from a functional point of view, certain retreats of its context and form are required.

We emphasis the fact that it is not necessary to limit the analysis only to the level of the indicators presented in the balance sheet, according to the law. This conclusion can be sustained by two situations:

- Some companies can use certain techniques to change the situation presented in the balance sheet. For example, a company that wishes to keep the appearance of a good liquidity can use a long term credit undertaken at the end of the year, which will increase the level of cash, by creating this way an apparent state of liquidity, very useful for the investors. At the beginning of the following year, the company could repay the credit in advance, returning this way to the 
initial situation. In these circumstances, an extern investor will not know the real situation of the company.

- Especially the companies with seasonal activity (hotelier societies, some fabrics from the textile industry, the agricultural companies). This seasonal character influences significantly the balance sheet, the situations of indicators presented at the end of the financial year, stop being relevant in the analysis.

Therefore, in order to trace these types of situations which describe the economical financial reality of a company, the informational valances must be overfulfilled, using previous retreats of the balance sheet, the most important out of them being the analysis of the balance sheet in terms of liquidity and exigibility, and the functional analysis. In order to present a valuable situation regarding the equilibrium, the financial position of a company we will use the financial analysis based on the balance sheet, taking into account two types of balance sheet: the functional and the financial balance sheet.

We present the connection between the accounting balance sheet and other two models:

Figure no. 1. The connection between the accounting balance sheet and other two models

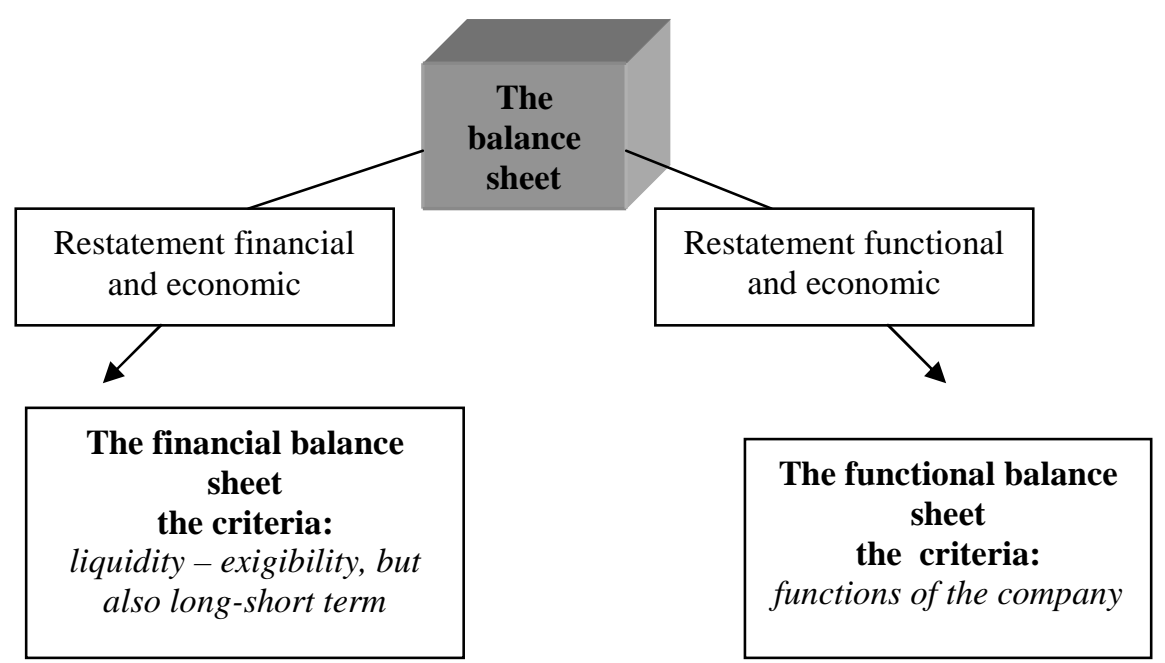

The drawing up and the informational valances of a financial balance sheet

Thus, the financial balance sheet is use to initially evaluate a company, regarding the sale, the solvability estimation, the structure and financial equilibrium analysis and so on. This type of balance sheet is very important for creditors and shareholders.

To accomplish the objectives presented above, the financial balance sheet regroups ascendancy the postulates of active after their liquidity (the possibility of converting the actives in cash), and regroups ascendancy the postulates of passive 
after their exigibility (ability of the company to pay its obligations at maturity), helping to the liquidity - solvability analysis.

In other words, the financial balance sheet has a positive influence on the notion of debt, because it permits to verify the company's capacity to face their debts with the actives [Mironiuc, M., 2006]. The credit institutions are very interested in the company's solvability (the ability of the firm to face their failing due obligations).

The drawing up of the financial balance sheet involves taking into account a series of recommendations (which will be presented below), recommendations that are the result of investigating the specialized literature:

- the actives evaluation is at their real value, respectively at their actual value (meaning their just value), taking into account that the analysis of the company's ability to face its obligations is based on this model of balance sheet. The differences resulting out of re-evaluation are recorded in the balance sheet by correcting the value of the re-evaluated actives or capitals. The plus from the capitals is considered by some authors a violation of the prudence principles [Marion, A., 2004];

- the assets purchase through operational leasing are included in the tangible category of assets, while the long or short term debts are increasing;

- the discount effects that aren't yet failing out increase the value of the claims, and are included in the category of short term debts;

- the premiums of obligations are diminished or included in the intangible assets;

- the net result of the financial year must be distributed;

- the latent fiscal debts concerning some elements of capital must be included in the category of one year longer debts;

- the risks and expenses provisions are redistributed to capitals, long, medium and short term debts, according to their objective and the probable date of use.

Some active or passive postulates must be treated again, in order to present a situation as real as it can, especially when the use of accounting principles or the use of some certain fiscal rules lead to dissimulations of the economic reality.

Taking into account the correlation presented above, the structure of the financial balance sheet can be as follows:

The structure of the financial balance sheet

Table no. 1

\begin{tabular}{|c|c|}
\hline Corrected assets & Corrected permanent capitals \\
\hline $\begin{array}{l}\text { Intangible immobilizations } \\
\text { - Expenses used when the company starts } \\
+ \text { Premium obligations } \\
\text { + Expenses distributed on several financial } \\
\text { exercises } \quad \text { Tangible assets } \\
\text { + Assets purchased through operational leasing } \\
\text { for the annuities remained to cover } \\
\quad \text { Financial assets } \\
\text { - Financial assets }<1 \text { year } \\
+ \text { Claims }>1 \text { year }\end{array}$ & $\begin{array}{l}\qquad \begin{array}{l}\text { Personal Capitals } \\
\text { (after the distribution of the result) }\end{array} \\
\text { - The value of the expenses used when a } \\
\text { company starts } \\
\text { Provisions for risks and expenses ( > } 1 \text { year) } \\
\text { Debts (>1 year) } \\
+ \text { The uncovered annuities of the assets } \\
\text { purchased through operational leasing, } \\
\text { annuities }>1 \text { year }\end{array}$ \\
\hline
\end{tabular}




\begin{tabular}{|l|l|}
\hline \multicolumn{1}{|c|}{ Corrected circulating active } & \multicolumn{1}{c|}{ Corrected short term debts } \\
\hline Stocks & Debts smaller than 1 year \\
Claims & (including the annuities < 1 year) \\
- Claims >1 year & + The value of discount effect \\
+ Discount effects whose value is still due & Provision for risks and expenses \\
Short term financial investments & (lower than one year) \\
+ Financial assets < 1 year & Revenues registered in advance \\
Cash & \\
Expenses registered in advance & \\
\hline
\end{tabular}

Source: adaptation Moroşan, J., 2009:154

The postulates from the balance sheet can be separated according to the liquidity - exigibility criteria and their length of time can be one year or lower. This type of structure highlights on the first level of the balance sheet, the assets and the permanent capitals and at the second level the short term debts and the circulating assets. This type of structure has a high homogeneity.

The financial balance sheet, drawn up this way, permits complex analysis regarding the solvability or the risk bankruptcy of a company, or the analysis of structure and financial equilibrium, whose results are important for the creditors to take place.

We return to the accounting balance sheet, as a starting point, to conduct the research of the financial balance sheet.

As some authors emphasize, the normalized balance sheet is a hybrid balance sheet, functional and patrimonial at the same time, although its presentation and the actives and passives classification is functional, while its content is patrimonial. If a functional balance sheet is the objective, then the balance sheet used as a basis is treated again in order to make it more functional and to get rid of the patrimonial right restrictions from the content point of view [Colasse, B., 2008]. If we check the specialized literature, we notice that the functional analysis of the balance sheet was developed by some authors who were bankers and was promoted by the Balance Sheet Central from France, in 1970.

\section{The drawing up and the informational valances of the functional balance sheet}

The functional balance sheet and its analysis appeared because of the necessity to understand the enterprise's needs and their financing methods, to realize a picture of different ongoing operating cycles [Niculescu, M., 2005].

Therefore, the elements of active and passive reflect the transitory values, passing structures in the transforming of a patrimony.

This idea was sustained by Bernard Colasse when he sustained that while the analysis of the financial balance sheet is made in terms of liquidity and exigibility, considering the balance sheet a situation of the company's patrimony, the functional analysis considers the balance sheet a situation of different roles given to the resources, presented at certain moment and not taking into account the juridical character of the resources. 
The drawing up of the functional balance sheet involves taking into account a series of recommendations (which will be presented below), recommendations that are the result of investigating the specialized literature:

- the actives are shown at their brute value;

- the depreciation and the depreciation provisions enter the category of passive;

- the current bank credits and the negative balances at banks are included in the category of loan and financial debts, (their value is mentioned briefly by referencing the balance sheet) and are isolated when the treasury is calculated;

- the discount effect are included in active at claims, while in passive at treasury credits (they are included here because the company must repay the banks if the client cannot pay the debts before the due time);

- the assets based on leasing are included into the functional balance sheet because they help the operating process, and the leasing is a source of financing, included in the category of traditional loan. In conclusion, the assets must be reintegrated into the active, and at the same time, the resources with the same volume are corrected (the depreciation amount for the depreciation part, respectively the financial debts for the un-depreciated part);

- the expenses registered in advance can be included either in the category of operating cycles or outside the operating cycle.

Taking into account the above correlation, the structure of the functional balance sheet can be the following:

The structure of the functional balance sheet

\begin{tabular}{|c|c|c|c|c|c|}
\hline \multicolumn{3}{|c|}{ ACTIVE } & \multicolumn{3}{|c|}{ PASSIVE } \\
\hline Stable & $\begin{array}{c}\text { Operating } \\
\text { immobilizations }\end{array}$ & \multirow[t]{2}{*}{ Investment } & \multirow{2}{*}{$\begin{array}{l}\text { Durables } \\
\text { resources }\end{array}$} & $\begin{array}{c}\text { Personal } \\
\text { resources } \\
\text { (among which } \\
\text { depreciations } \\
\text { and the } \\
\text { adjustments) }\end{array}$ & \multirow{2}{*}{$\begin{array}{l}\text { Financing } \\
\text { Function }\end{array}$} \\
\hline Uses & $\begin{array}{c}\text { Immobilizations } \\
\text { outside operating } \\
\text { activity }\end{array}$ & & & Long term loans & \\
\hline \multirow{2}{*}{$\begin{array}{c}\text { Circulating } \\
\text { Cooperating } \\
\text { Assets }\end{array}$} & Stocks & Operating & \multirow[t]{2}{*}{ Operating } & \multirow[t]{2}{*}{ resources } & \multirow{2}{*}{$\begin{array}{l}\text { Operating } \\
\text { function }\end{array}$} \\
\hline & Operating claims & Function & & & \\
\hline $\begin{array}{c}\text { Circulating } \\
\text { outside }\end{array}$ & $\begin{array}{c}\text { assets } \\
\text { operating } \\
\text { activity }\end{array}$ & $\begin{array}{l}\text { Financing } \\
\text { function }\end{array}$ & $\begin{array}{l}\text { Resources } \\
\text { Operating }\end{array}$ & $\begin{array}{l}\text { outside } \\
\text { activity }\end{array}$ & $\begin{array}{l}\text { Financing } \\
\text { function }\end{array}$ \\
\hline $\begin{array}{l}\text { Active } \\
\text { (cash) }\end{array}$ & treasury & $\begin{array}{l}\text { Financing } \\
\text { function }\end{array}$ & $\begin{array}{l}\text { Passive } \\
\text { (short } \\
\text { credits }\end{array}$ & $\begin{array}{c}\text { treasury } \\
\text { term banking } \\
\text { received) }\end{array}$ & $\begin{array}{l}\text { Financing } \\
\text { function }\end{array}$ \\
\hline
\end{tabular}

Source: adaptation Vintilă, G., 2006:116 
We must make supplementary observations, regarding the above classification. Therefore, the durable resources include the capitals, the financial debts (not the premium obligations), but also the depreciation and the adjustments for the assets depreciation. The reason the depreciation is included along other elements of capital is that the depreciation in the financial view, is an element of self-funding [Cohen, E., 2007].

The operating resources include the operating debts, advances received from clients, revenues in advances but outside the operating cycle, and in the operating circulating assets includes the stocks and ongoing production, the advance given to suppliers, operating claims, advance expenses related to the operating activity (we mention that all these elements are registered in the balance sheet at their entering value).

According to the classification from the functional balance sheet, the circulating assets and the Resources outside operating are separately registered. The latter includes the short term financial investments, the debts resulting from the acquisition of assets; those expenses and revenues registered in advance which are not related to the operating activity.

From the functional balance sheet point of view, the treasury actives and passive is not vital. In other words, the net treasury indicator is not fundament for the functional analysis [Buşe, L., 2005].

In order to investigate the enterprise's activities on operating cycles, the functional balance sheet must regroup the postulate of active and passive after the function which is accomplished on cycles of activities, like: investments, financing and operating.

Thus, the investments cycle - contains all the funds engagements, realized according to the objectives of the enterprise, in order to obtain some cash flows or cash equivalents. According to IAS 7 "The cash flows situation", the investments are the acquisitions of actives on long germ, but also other investments which are not included into the category of cash.

The financing cycle - contains both the transactions between the company and the capital investors (creditors, shareholders), and the transactions concerning the distribution of the result.

The operating cycle - is the fundamental cycle of the functional analysis, which permits to supplying, production, operations in continuum and permanent flow to take place. According to IAS 7 'The cash flows situation", the activities are the main activities that generated revenues in a company.

We notice that a functional balance sheet does not take into account the long or short term criteria, when it classifies the active, capital and debts postulates.

Our conclusions, from what was discussed above, will highlight the importance and necessity of drawing up these two types of balance sheet, since they give the opportunity of a superior informing: 
Advantages: Financial balance sheet - Functional balance sheet

\begin{tabular}{|c|c|}
\hline Financial balance sheet & Functional balance sheet \\
\hline $\begin{array}{l}\text { Advantages: } \\
\text { - serves for an extern analysis, on which } \\
\text { the creditors are interested } \\
\text { - is structured on liquidity - exigibility } \\
\text { criteria, but also long-short term criteria, } \\
\text { is very useful in the analysis of the } \\
\text { insolvability risk of a company } \\
\text { - is useful in an initial evaluation of the } \\
\text { enterprise, when the sale or liquidation is } \\
\text { considered } \\
\text { - the financial approach of the balance } \\
\text { sheet is based on the liquidity hypothesis } \\
\text { of an entity, meaning that in case the } \\
\text { company stops its activity, the main } \\
\text { information on the ability to pay the } \\
\text { debts are given by this model of balance } \\
\text { sheet } \\
\text { - serves in the analysis of the structure and } \\
\text { the financial equilibrium }\end{array}$ & $\begin{array}{l}\text { Advantages: } \\
\text { - serves to an intern analysis, on which the } \\
\text { management is interested } \\
\text { - the analysis of the functional balance } \\
\text { sheet permits the management of the } \\
\text { company to anticipate the influence that } \\
\text { transactions specific to investment, } \\
\text { operating and financing functions have } \\
\text { on treasury } \\
\text { - the functional analysis follows, beside } \\
\text { the investigation of the company's } \\
\text { activity on operating cycles, also the } \\
\text { modalities of financing of a company, } \\
\text { with the objective of reaching an } \\
\text { optimum structure with regard to the } \\
\text { financing } \\
\text { - the functional approach of the balance } \\
\text { sheet is based on the ongoing activity } \\
\text { principles, and takes into its modality of } \\
\text { responding to an dynamic analysis } \\
\text { requirements } \\
\text { - serves in the analysis of the functional } \\
\text { equilibrium }\end{array}$ \\
\hline
\end{tabular}

In our research regarding the two types of balance sheet we have found also in the specialized literature, criteria used in the functional analysis of the functional balance sheet [Colasse, B., 2008]. The main aspects referred to: established resources, the hypothesis of successive allocation of the resources established by users, the role of treasury.

Regarding the established resources - there has been a debate on the noninclusion of the current bank credit in this category. We agree with them, if we take into account the fact that banks are automatically renew the treasury credits, giving them a similar stability with the one of long term loans. Also, if we consider from the accounting theory point of view, and the definition given to current bank credits, then they are included into the category of passive treasury (according to the structure of the functional balance sheet presented above).

Regarding the successive allocation of the resources established for assets, and then the circulating fund, it is not incorrectly or exaggerated from the theoretical (it establish a connection much too rigid between the investment decisions and the financing decisions) and practical point of view (it contradicts the unity principles according to which the resources finance the users). If the difficulty of defining these established resources and if the priory of distribution of these resources for assets is contested, then a powerful doubt regarding the notion of functional circulating fund appears. 
The third element which was debated, the role of treasury: it can only be the result of reconciliation between the circulating fund and the circulating necessity, but also it can be a real use.

Taking into account these critiques, many authors consider necessary not including the notion of circulating fund, but also the notion of treasury, in order to keep in the functional analysis only the notion of need for circulating fund and the use of a Pools de fonds balance sheet.

The "Pool de fonds" balance sheet

Table no. 4

\begin{tabular}{|c|c|c|}
\hline $\begin{array}{c}\text { Industrial and commercial } \\
\text { uses }\end{array}$ & Brute assets & \multirow{2}{*}{ Personal Resources } \\
\cline { 2 - 2 } & Brut operating NFR & $\begin{array}{c}\text { Borrowed resources } \\
\text { (which include the current } \\
\text { bank loans) }\end{array}$ \\
\hline Financial uses & Financial assets & Cash \\
\cline { 2 - 2 }
\end{tabular}

Source: adaptation Colasse, B., 2008: 136

We notice that this models of balance sheet is much more interesting, because it present the financing and investment policy of the company, but at the same time it does not offer all the instruments necessary to a solid analysis, including the risk bankruptcy of a company (starting from the rate of personal needs and those borrowed, there are few information offered regarding the major objective: the bankruptcy risk).

\section{Conclusions}

For the initial evaluation of an enterprise, and the solvability or risk bankruptcy estimation, for the structure analysis and the financial/functional equilibrium, for the analysis of the company on operating cycles and their role in the functioning of the company, we need also other information, beside those given by the normalized balance sheet. The normalized balance sheet is a hybrid balance sheet, with limited informational valances.

This type of analysis can be conducted based on the financial or functional balance sheet. Starting from the balance sheet, through different category of group after specific criteria, these two balances sheet can be drawn up.

It is important to mention that, these models of balance sheet are not normalized; they are the result of accounting specialists. Thus, it is normal and constructive at the same time, that these specialists to hold back when they are using certain criteria, some of them presented by us in this paper.

The importance and the use of these balance sheets is that it helps in complex analysis, when previsions are made, by adding value to the classic balance sheet. 


\section{References}

- Buşe, L. (2005), Analiză economico-financiară, Bucureşti: Editura Economică.

- Colasse, B. (2008), L'analyse financière de l'entreprise, 5 ed, Paris: Editura La Decouverte.

- Cohen, E. (2007), Analyse financière 5 ed, Paris: Economica.

- Gădău, L. (2014), Intocmirea, prezentarea şi utilizarea situaţiilor financiare. Studii şi cercetări, Bucureşti: Tribuna Economică.

- Ionescu, L., \& Buhur, S. (2015), The Fiscal and Financial Control Reform in Romania and Turkey: A Comparative Study, Annals of Spiru Haret University, Economic Series, vol. 6(15), issue 2, p. 27-34. ASE.

- Işfănescu, A., et al. (2002), Analiză economico-financiară, Bucureşti: Editura

- Moroşan, J. (2009), Analiză economico-financiară. Metode şi tehnici, Bucureşti: Editura Fundaţiei România de Mâine.

- Mironiuc, M. (2006), Analiză economico-financiară, Iaşi: Sedcom Libris.

- Marion, A. (2004), Analyse financiere: conceptes et methodes, Paris: Dunod.

- Năftănăilă, C.A. (2010), Financial Crisis And Romania's Economy, Annals of Spiru Haret University, Economic Series, vol. 1(10), issue 2, p. 85-90.

- Niculescu, M. (2005), Diagnostic financiar, Bucureşti: Economică.

- Stroe, R. (2004), Gestiunea financiară a întreprinderii: Note de curs şi aplicaţii, Bucureşti: Editura ASE.

- Țole, M. (2004), Analiză economico-financiară, Bucureşti: Editura Universitară.

- Vintilă, G. (2006), Gestiunea financiară a întreprinderii, Bucureşti: Editura Didactică şi Pedagogică. 
